\title{
Measurement Issues in Financial Placement and Technical Provisions of Czech Insurance Companies ${ }^{\#}$
}

\author{
Jiřina BOKŠOVÁ*
}

Measurement represents one of the most important methodological elements of accounting because it affects the overall informative ability of financial statements. The chosen measurement method affects not only the size of assets and liabilities, but the size of costs and revenues of the entity as well; therefore it has a major impact on profit and solvency of insurance companies. Each accounting regulation at national or supranational level includes relatively thorough provisions related to valuation.

According to Chorafas (2006), in the last three decades of the 20th century valuing assets in a way different than classical book value has been the strength of corporate raiders, who were able to see further than others. Because being ahead of the curve is one of the secrets of success in business, it is good news that fair value has become the generalized new accounting regime, which can affect every entity and every process. This includes:

- banks as financial intermediaries;

- insurers as providers of basic social services; and

- the distribution of financial risks among economic agents.

The Czech measurement system regulated in Accounting Act distinguishes between the initial and the subsequent measurement of assets and liabilities.

\# This paper was prepared in the framework of research plan Development of Accounting and Financial Theory and its Application in Practice from Interdisciplinary Point of View (registered number MSM 6138439903).

Jiřina Bokšová, - Associate Professor; Department of Financial Accounting and Auditing, Faculty of Finance and Accounting, University of Economics, Prague, W. Churchill Sq. 4, 13067 Prague, Czech Republic; <boksova@vse.cz>. 


\section{Initial Measurement}

This measurement is based on the actual (current) costs (prices), which need to be expended for the acquisition of assets, or their estimation. The specific method of valuation depends on the way of acquisition of an asset (rise of liability).

Companies use upon initial measurement following measurement bases:

- Purchase price - the price at which the assets were acquired and cost related with the acquisition. This method is used for valuing tangible assets excluding internally created tangible assets, intangible assets except claims and internally created intangible assets, inventories with the exception of internally created inventories, shares, securities, derivatives and claims for payment and rise of liabilities.

- Costs of production -used in the case of internally created estates. $^{1}$

- Replacement costs - the acquisition price of the assets when they were acquired. This method is used for measurement of assets, which were obtained for free (except cash, valuables and claims) as well as property, whose cost of production cannot be identified or they are higher than replacement costs.

- Nominal value $^{2}$ - cash, valuables, claims and liabilities incurred.

\section{Subsequent Measurement}

Subsequent measurement is based on two concepts:

- historical prices (i.e. historical costs);

- fair value.

Historical costs are related to the original costs of acquisition (cost of acquisition) and it can only be decreased due to depreciation or in case of the impairment of an asset.

Purchase price and costs of production represent historical prices.

2 Represents the amount of money, that is assigned to a part of property in order to identify such property. 
Fair value on the other hand allows the amount recorded for the property not only to be decreased, but also to be increased above the level of the original costs of acquisition. The term fair value according to Czech legislation is not the same as fair value according to IFRS. Even though both approaches to determine fair value are based on the same bases, they are applied in some cases in Czech legislation differently.

\section{Fair Value Approach}

According to Accounting Act, fair value shall be applied for following balance sheet items:

- Securities, excluding securities held to maturity, bonds issued in primary offerings, which are not set for trading, securities representing subsidiaries or associates and securities issued by the entity;

- Derivates;

- Financial placement and technical provisions for the entities that provide insurance or securing activity according to specific legislation, except for public health insurance;

- Assets and liabilities in case of conversion of the companies or cooperatives with the exception of the change in legal form or in other cases according to special legislation, which requires fair value valuation in accordance with special legislation;

- Part of the assets and liabilities hedged by derivatives.

- Claims, that the entity acquired and set as claims for trading,

- Obligations to return securities that the entity had stolen and at the time of valuation are not regained.

According to the fair value are measured in commercial insurance companies financial placement (funds that are intended to cover insurance liabilities from insurance contracts) and insurance technical provisions.

Fair value is determined in accordance with Czech legislation as:

- The market value, understood as the value that is announced (the latest) at the time of valuation at domestic or foreign stock exchange or another regulated market, i.e. the value that is at this moment the closest;

- Qualified expert opinion valuation or expert estimation, unless there is no market value, or if this value does not represent fair 
value. It is desirable that the final valuation based on expert opinion should be close to the market value;

- Valuation according to special regulations, if any of the previous methods cannot be used.

\section{Financial Placement in Commercial Insurance Companies}

By "financial placement" we mean ways and forms of assets placing; their sources are technical reserves or own sources of the insurance company. In the Czech Republic the configuration of the financial placement for commercial insurance companies is controlled by law and since 2002 valuated at fair value.

Other assets reported in the financial statements of commercial insurance companies - tangible, intangible fixed assets and inventory, that are not financial placement, are at the reporting date valuated in historical costs.

The law about insurance business embodies into the compilation of financial placement these kinds of investments:

- Estates and buildings - they are operational immovable assets that the insurance company use solely for insurance and securing activity and about non-operational immovable assets, revaluation of estates and buildings to the date of final accounts on a fair value is caught on valuation on balance items, buildings are not depreciated,

- Shares, beneficial interest - revaluation of this group of property is caught on balance items valuation,

- Another financial placement - bonds, participation certificates, debit notes, derivates, bank deposits are re-valued to the fair value which is caught on valuation on income statement,

- Financial placement of life insurance if the bearer of the investment risk is the policy holder - policy holders share in the profits from investments (e.g. unit linked), overvaluation of this group of property to the date of final accounts on the fair value which is caught on valuation on income statement.

The evolution of valuating of financial placement in Czech Republic can be seen in Tab. 1 and Tab. 2 . 
Bokšová, J: Measurement Issues in Financial Placement and Technical Provisions of Czech Insurance Companies.

Tab. 1: Evolution of valuation of financial placement at the transaction date

\begin{tabular}{|c|c|c|c|c|}
\hline $\begin{array}{c}\text { Valuation } \\
\text { at the } \\
\text { reporting } \\
\text { date }\end{array}$ & Until 2002 & Year 2002 & Year 2003 & Since 2004 \\
\cline { 2 - 4 } & \multicolumn{3}{|c|}{ Stays in historical cost } \\
\hline
\end{tabular}

Source: Bokšová (2010)

Valuation at the transaction date in historical costs is consistent with IFRS.

Tab. 2: Evolution of valuation of financial placement at the reporting date

\begin{tabular}{|c|c|c|c|c|}
\hline \multirow{2}{*}{$\begin{array}{c}\text { Valuation } \\
\text { at the } \\
\text { reporting } \\
\text { date }\end{array}$} & Until 2002 & Year 2002 & Year 2003 & Since 2004 \\
\hline & $\begin{array}{l}\text { Historical or } \\
\text { market value } \\
\text { (lower) }\end{array}$ & \multicolumn{3}{|c|}{ Fair value } \\
\hline \multicolumn{2}{|c|}{ Reported into equity } & $\begin{array}{l}\text { All securities } \\
\text { except from } \\
\text { securities } \\
\text { held for } \\
\text { trading }\end{array}$ & $\begin{array}{l}\text { Land, } \\
\text { properties } \\
\text { and } \\
\text { constructions } \\
\text { Equity } \\
\text { participations }\end{array}$ & $\begin{array}{l}\text { Land, } \\
\text { properties } \\
\text { and } \\
\text { constructions } \\
\text { Equity } \\
\text { participations } \\
\text { Derivatives } \\
\text { Objects and } \\
\text { works of } \\
\text { cultural and } \\
\text { artistic value } \\
\text { Securities } \\
\text { held to } \\
\text { maturity }\end{array}$ \\
\hline \multicolumn{2}{|c|}{$\begin{array}{c}\text { Reported into income } \\
\text { statement }\end{array}$} & $\begin{array}{c}\text { Other items } \\
\text { of financial } \\
\text { placement }\end{array}$ & $\begin{array}{l}\text { Securities } \\
\text { held for } \\
\text { trading }\end{array}$ & $\begin{array}{c}\text { Other items } \\
\text { of financial } \\
\text { placement }\end{array}$ \\
\hline Depreciation & \multicolumn{3}{|c|}{ Yes, from historical costs } & No \\
\hline Impairment & Yes & & No & \\
\hline
\end{tabular}

Source: Bokšová (2010) 
Valuation of financial placement at the reporting date is characterized by several differences, compared to IFRS.

Before 2002, the items of financial placement at the reporting date were measured at historical costs. There was a possibility to depreciate these assets and in case of temporary decrease of value of assets it was possible to create an impairment of these assets in accordance with prudence.

The market value of assets in financial placement was determined at the reporting date. When it was not possible to determine reliable market value, measurement according to present value of discounted revenues from the asset was used. When it was found, that the value of asset is lower than the value in accounting, the insurance company had to create the impairment of this asset.

After 2002 the measurement method of financial placement upon reporting date in commercial insurance companies passed through significant amendments, which brought lower year-on-year comparability of reported information for few years. In $2002^{3}$, when the revaluation of land, buildings and constructions in financial placement in insurance companies' reports on fair value according to Czech legislation for the first time, the differences between historical costs or amortized costs and fair value was recorded as revenues or expenses, which means that the difference influenced profit (income) of reported period. During that year the unearned income of the revaluation financial placement on higher fair value could leave the insurance company as reported profit (the unearned income could have been paid as dividends or share of profit $)^{4}$.

The financial assets measurement at fair value was in 2002 (except for reporting of bonds held to maturity, which were in Czech Republic also reported at fair value) in conformity with international standard IAS 39 Financial Instruments: Recognition and Measurement.

In 2003 Czech legislation attempted to solve fundamental impact permitted by legislation in 2002. Land, buildings and constructions were that year first time revaluated on fair value, credit or debit of capital reserves from revaluation, which are part of insurance companies' equity.

\footnotetext{
Amendment of Accounting law No. 353/2001 Sb.,

4 It was legally possible to tunnel insurance companies in 2002.
} 
For financial assets, the division of portfolio of financial instruments intended by the entity ended in that year (entity could decide to hold it or deal with it otherwise) and the method of division of portfolio according to the entity, that issue the financial assets has started. Both property and debt items of financial placement in entities were revaluated at fair value to the capital reserves, regardless of whether they were securities held for trading or not; for other financial assets into the profit. That year there was a significant diversion from IAS 39 - Financial Instruments: Recognition and Measurement.

In 2004 additional change in accounting for land, property and constructions was made. Land, properties and constructions are revalued at fair value in the capital reserves, properties are not depreciated since 1 January 2004. Depreciation of properties is captured into fair value of this asset, which can rise or fall. Decrease in fair value due to depreciation will decrease the equity.

In 2004, bonds held to maturity are in financial assets accounting still revaluated at fair value (what is contrary to the IAS 39), property and debt securities issued by entities, where the insurance company has decisive or significant influence, are revaluated into the balance sheet (similar to the year 2003). Other assets are valued same as in IAS 39.

\section{Measurement of Technical Provisions upon Balance Sheet Day}

Since 2002 insurance technical provisions are measured at "fair value". Czech Republic, as one of the first countries, allowed not only valuation of financial placement at "fair value", but also the valuation of insurance technical provisions at "fair value". But in the Czech regulations, there are not instructions how to value these insurance technical provisions at "fair value"

According to the law, it is not possible to use market value as fair value when valuating insurance technical liabilities, because there is no active insurance technical liabilities market. Next possibility is to value according to specific legislation, which could only be Insurance law. According to this Insurance law the insurance technical provisions must be measured according to the same statistical support documents and the same interest rate as were used in the computation of the premium rates.

5 Until now, nor IFRS allow valuation of insurance technical liabilities in fair value. 
Third option how to determine the fair value of provisions is to use expert valuator estimation. This valuator is insurance mathematician, who confirm "fair value" with his signature and thus correctness and sufficiency of technical provisions. It is standard way of valuation, which we just formally call "fair value".

Declaration of technical provisions in practice at "fair value" is a formal act that currently has nothing to do with the "fair value" as understood by IFRS. Technical provisions in the Czech Republic are tested for their sufficiency upon balance sheet date (as according to IFRS $4)^{6}$.

\section{Conclusion}

There are some problems in implementation of fair value measurement upon balance sheet day in the Czech Republic. Fair value is not defined in Czech accounting legislation. There is mentioned only set of ways how to set this fair value in legislation.

According to the Accounting Act, fair value should be determined as market value. If it is not possible to determine the market value, fair value is determined according to estimate on the market basis. But how to determine this estimate is not given in legislation.

It seems to be totally unacceptable the statement to determine fair value according to specific legislation. This legislation is primarily the Property valuation law. This law serves especially for taxation purpose and for the valuation task it does not take into consideration particular purpose of the asset in an entity. Determination of fair value should be based on accounting legislation to provide consistency in reported items in statement of financial position of the entity.

Catty (2010) states that "Professional judgment is always involved in a valuation, even if only with respect to knowledge of the asset or business; no one would hire a real estate specialist to determine the fair market value of antique furniture, nor a financial expert for insurable values of machinery or equipment. However, these distinctions, while well known and understood, deal only with training and experience. A different, also

\footnotetext{
${ }^{6}$ For comparison see Casualty Actuarial Society (2008), Berquist and Sherman (1977). Taylor, McGuire and Greenfield (2003).
} 
important, kind of judgment, which users of valuation information often disregard, is that normally there is really not a single answer but a range of correct answers in any specific valuation situation, whether for real estate financing, placement of insurance, or an allocation of the purchase price in a business combination."

Another crucial problem is inconsistency of fair value as a valuation basis according to IFRS. Kovanicová (2009) says that also in international terms the conception of fair value application goes through significant changes. Current more precise formula specifies "Fair value is the price that would be obtained when selling an asset or paid to transfer the liability in an ordinary transaction between market participations at the measurement date."

Fair value measurement is valuation method based on market basis (market-based measurement). Fair value is not the price of realized transaction; it is a price of hypothetical transaction at the valuation date; it is considered from the view of an entity that controls the asset respectively (in case of liability) that owns the liability. The entity does not apply its view, but it takes the position of hypothetical market participation. That means that the specific factors for particular (reporting) entity, which could influence the transaction, are not taken into consideration. From this short definition of fair value formula according to IFRS it can be clearly seen the different perspective on fair value valuation method according to Czech legislation and IFRS. Comparing the current Czech situation with other Central European countries, it is in line with results described in Meluchová (2009).

Issue of valuation of insurance technical provisions in fair value is also untimely. Until now, regulations for valuation of insurance technical provisions at the reporting date were not approved internationally (Bokšová, 2008). Nowadays some valuation bases for insurance technical provisions are tested (e.g. current exit value, current fulfillment value). When the testing of impact on reporting of commercial insurance companies will end and mathematical models will be tuned, one of the valuation bases will be used for reporting of these insurance liabilities. It is assumed that the standard that will recommend new valuation basis for insurance technical provisions will take effect in 2015. 


\section{References}

[1] Berquist, J. R. - Sherman, R. E. (1977): Loss Reserve Adequacy Testing: A Comprehensive, Systematic Approach. [on-line], Proceedings of the Casualty Actuarial Society Casualty Actuarial Society, 1977, vol. 67, no. 6, pp. 123-184, [cited 20 ${ }^{\text {th }}$ March, 2008], 〈http://casualtyactuaries.com/pubs/proceed/proceed77/77123.pdf>.

[2] Bokšová, J. (2008): Financial Placement and Technical Reserves in Insurance Accounting. European Financial and Accounting Journal, 2008, vol. 3, no. 2, pp. 87-100.

[3] Bokšová, J. (2010): Accounting of Insurance Companies - Specifics in the Czech Republic. (In Czech: Účetnictví komerčních pojištovenspecifika v ČR.) Prague, Wolters Kluwer, 2010.

[4] Casualty Actuarial Society (2008): Statement of Principles. [on-line], Arlington, Casualty Actuarial Society, c2008, [cited 20 ${ }^{\text {th }}$ March, 2008], <http: //www.casact.org/standards/princip>.

[5] Catty, J. P. (2010): Wiley Guide to Fair Value Under IFRS: International Financial Reporting Standards. New York, Wiley, 2010.

[6] Chorafas, D. N. (2006): IFRS, Fair Value and Corporate Governance: The Impact on Budgets, Balance Sheets and Management Accounts. Oxford, CIMA Publishing, 2006.

[7] Kovanicová, D. (2009): Fair Value in a New Overcoat? About IFRS ED "Fair Value Measurement" (In Czech: "Fair value" v novém kabátě? O návrhu standardu IFRS “Ocenění na bázi fair value”). Účetnictví, 2009, vol. 56, no. 12, pp. 2-8.

[8] Meluchová, J. (2009): Accounting and Reporting of Insurance Companies under IFRS (In Slovak: Účtovnictvo a vykazovanie poistovní podl'a IFRS.) Bratislava, Wolters Kluwer, 2009.

[9] Taylor, G. - McGuire, G. - Greenfield, A. (2003): Loss Reserving Techniques: Past, Present and Future. Melbourne, University of Melbourne, Research no. 109, 2003. 


\title{
Measurement Issues of Financial Placement and Technical Provisions of Czech Insurance Companies
}

\author{
Jiřina BOKŠOVÁ
}

\begin{abstract}
Measurement represents one of the most important methodological elements of accounting because it affects the overall informative ability of financial statements. The chosen method of valuation affects not only the amount of assets and liabilities, but the size of costs and revenues of the entity as well; therefore it has a major impact on profit and solvency of insurance companies. Each accounting regulation - whether at national or supranational level - includes relatively thorough provisions related to valuation. In the Czech accounting system valuation is regulated by the Accounting law, which distinguishes between the initial valuation of assets and liabilities (valuation at the transaction date) and the subsequent valuation of assets and liabilities "at the end of the reporting date". However, the Czech definition of fair value at the national level is different from IFRS at the supranational level, which causes issues with reporting assets and liabilities of insurance companies. By 2015, a new IFRS is expected to be issued, dealing with insurance reporting issues, including "fair value". This new standard is expected to address current deficiencies in insurance reporting guidance.
\end{abstract}

Key words: Insurance; Financial placement; Technical reserves; Historical cost; Fair value.

JEL classification: G22, M41. 